EPiC Series in Engineering
Volume 3, 2018, Pages 1332-1339
HIC 2018. 13th International
Conference on Hydroinformatics

\title{
Impact of Climate Change on Irrigated Agriculture in Sardinia region
}

\author{
Sara Masia ${ }^{1,2}$; Janez Sušnik ${ }^{2}$; Serena Marras ${ }^{1,3}$; Simone Mereu ${ }^{1,3}$; Donatella \\ Spano ${ }^{1,3}$; Antonio Trabucco ${ }^{1,3}$ \\ ${ }^{1}$ University of Sassari, Department of Agriculture, Sassari Italy \\ ${ }^{2}$ Integrated Water Systems and Governance Department, IHE Delft Institute for Water Education, \\ Delft, The Netherlands \\ ${ }^{3}$ Euro-Mediterranean Center on Climate Changes, IAFES Division, Sassari, Italy \\ Corresponding author: s.masialun-ihe.org
}

\begin{abstract}
Increased drought risk in Southern Europe is expected due to changing rainfall patterns and increasing evapotranspiration. Water availability is crucial in semi-arid Mediterranean countries, where irrigation is essential for crop production.

In this work, irrigated agriculture vulnerability of three Sardinian irrigation districts and their associated reservoirs is assessed. The simultaneous impact of climate change on water inflow to the reservoir, open surface evaporation, and water supply is evaluated and then integrated into indicators. Vulnerability Index is calculated to define future reservoir adequacy in guaranteeing irrigated crops. The analysis is conducted by comparing the baseline (1976-2005) with the future (2036-2065) climate under RCP 4.5 and 8.5. The Simulation of Evapotranspiration of Applied Water model is incorporated into a GIS platform to compute crop irrigation demand. Changes in water inflow to reservoirs and evaporation losses are estimated. Results show a decreasing resilience and increasing vulnerability of irrigated agriculture under climate change in each case study. The highest resilience is estimated in Monte Pranu and Stretta di Calamaiu reservoir while the highest vulnerability in the Cuga-Alto Temo system. Climate change may only partially affect irrigation in resilient systems, where storage capacity and water entering into the reservoir is higher than water outflow.
\end{abstract}

Keywords: Irrigation demand; Mediterranean; reservoirs; vulnerability, water management

Highlights

- Irrigated agriculture vulnerability is assessed in three irrigation districts in Sardinia region

- The strongest impact of climate change on irrigated agriculture is estimated in the CugaAlto Temo system district

- $\quad$ Decreasing reservoir resilience is expected due to future declining water availability.

G. La Loggia, G. Freni, V. Puleo and M. De Marchis (eds.), HIC 2018 (EPiC Series in Engineering, vol. 3), pp. $1332-1339$ 


\section{Introduction}

In the last few decades, the interest of food security and rural development is increasing particularly in Mediterranean countries already affected by water scarcity [1]. The strong reduction of the frequency of precipitation events leads to decreasing water availability for sectors in Southern Europe [2]. Evapotranspiration is also expected to increase due to climate change, with an influence on crop water application. Water supplied by irrigation becomes essential when precipitation does not compensate crop water demand, with an unavoidable effect on crop growth and yield. Several studies highlight the increasing crop water requirements under climate change conditions $[3,4]$.

Since irrigation is necessary to sustain crop production in arid and semi-arid areas, strategies aimed to improve sustainable management of water resources are needed. In this context, in depth studies on irrigated agriculture vulnerability and reservoir resilience under climate change conditions are required.

This work develops a methodology to assess the impact of global warming on irrigated agriculture. The analysis is conducted in three irrigation districts located in Sardinia region. The impact of climate change is assessed on both water inflow to reservoirs and water allocated for agricultural use to define the future level of reservoir adequacy to ensure irrigated agricultural production in the island.

\section{Material and Methods}

\subsection{Methodology}

This work assesses the irrigated agriculture vulnerability under climate change for three Sardinian irrigation districts and their related reservoirs, which are prevalently used for irrigation.

The impact of climate change on water shortage is computed by adding changes in water entering the reservoir, changes in water used for irrigation, and evaporation losses from baseline conditions to future projections.

\subsection{Study sites}

Three irrigation districts and four reservoirs located in Sardinia are selected through the Global Reservoir and Dam (GranD) database [5] (Table 1 and Figure 1).

\begin{tabular}{|c|c|c|c|c|c|c|}
\hline ID & Res & Total irrigated area (ha) & $\begin{array}{c}\text { Surface } \\
\text { area } \\
\left(\mathrm{km}^{2}\right)\end{array}$ & $\begin{array}{c}\text { Basin } \\
\text { area } \\
\left(\mathrm{km}^{2}\right)\end{array}$ & $\begin{array}{c}\text { Cap } \\
\left(\mathbf{M m}^{3}\right)\end{array}$ & Re \\
\hline Gallura & $\begin{array}{l}\text { Stretta di } \\
\text { Calamaiu }\end{array}$ & 1402 & 5.7 & 339 & 105.2 & 0.45 \\
\hline \multirow[b]{2}{*}{ Nurra } & Cuga & \multirow[b]{2}{*}{4704} & 3 & 73 & 31.7 & 0.42 \\
\hline & $\begin{array}{l}\text { Alto } \\
\text { Temo }\end{array}$ & & 4.99 & 124 & 95.7 & 0.42 \\
\hline $\begin{array}{l}\text { Basso } \\
\text { Sulcis }\end{array}$ & $\begin{array}{l}\text { Monte } \\
\text { Pranu }\end{array}$ & 1383 & 6.98 & 420 & 62 & 0.32 \\
\hline
\end{tabular}

Table 1: Main characteristics of the selected reservoirs. ID = Irrigation District, Res $=$ reservoir, Cap $=$ reservoir capacity, Rc = Runoff coefficient. 


\subsection{Climate data}

Daily climate data from the Global Circulation Model (GCM) CMCC-MED [6,7] downscaled with a Regional Climate Model (RCM) at a spatial resolution of $14 \mathrm{~km}$ are used to represent climate conditions for the baseline (1976-2005) and the future (2036-2065), under RCP 4.5 and 8.5 climate scenarios, and to define changes in crop water demand, evaporation losses, and inflow to reservoirs.

\subsection{Total water inflow}

Water inflow is computed as the product of the basin runoff coefficient, upstream basin area, and mean annual precipitation. The digital elevation model (DEM) developed by SRTM gap-filled from CSI-CGIAR is used as input in the ArcGIS hydro-tool software to compute the watershed area contributing to each reservoir. The runoff coefficient used to convert the amount of precipitation to runoff is computed as the ratio between mean annual runoff and mean annual precipitation both estimated from 1950 and 2000. Modelled runoff values are validated against observed data.

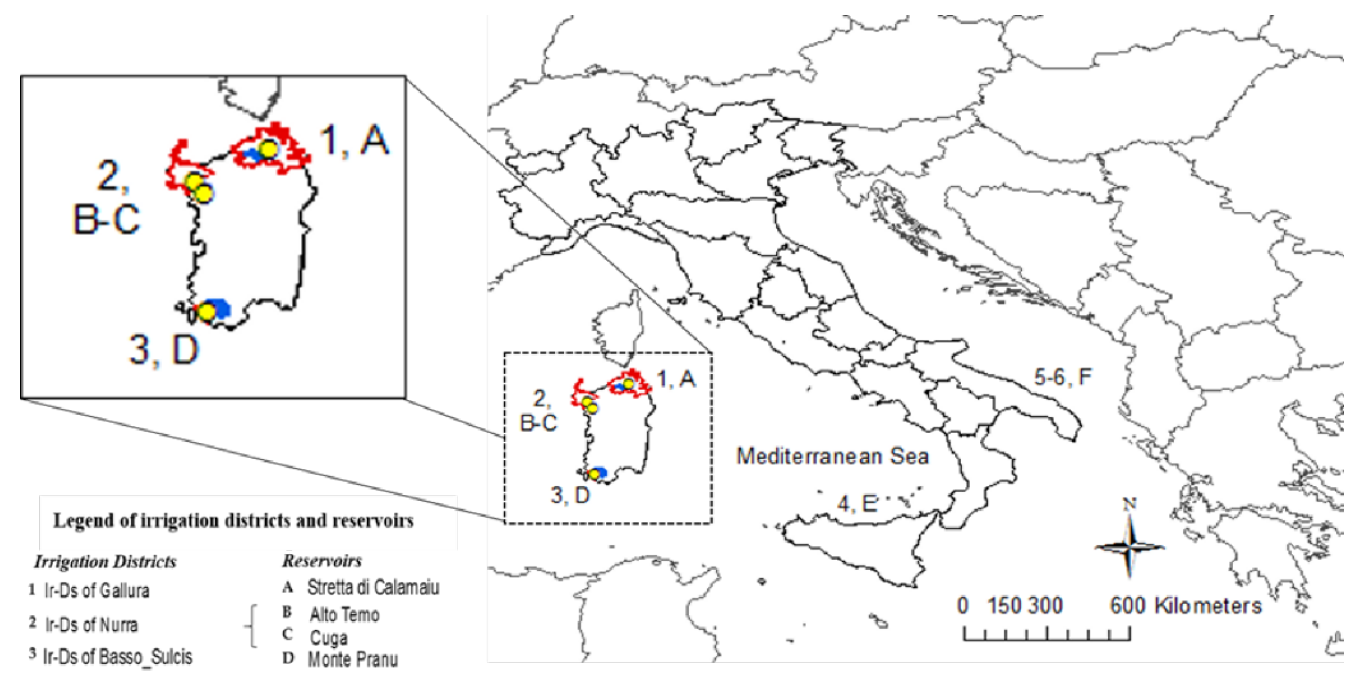

Figure 1: Irrigation districts (red perimeters), reservoirs (yellow points), and basins (blue areas).

\subsection{Total water distribution}

Irrigated area and crop water demand are used to estimate the total water required to satisfy agricultural needs in each district. The total water used to satisfy agricultural needs is estimated by computing the irrigated hectares by crop types and the related crop water demand.

In this work the original version of the Simulation of Evapotranspiration of Applied Water (SIMETAW\#) model, developed by Snyder et al. [8,9] and recently modified by Mancosu et al. [10], was re-written in "R" programing language (SIMETAW_R) and coupled to GIS libraries (SIMETAW_GIS) to develop a platform to automate interactions between environmental and climate data to process the soil water balance for multiple years and pixels across regional and continental scales. The platform is used to calculate the spatial distribution of yearly crop water demand and the number of net water applications for irrigated crops in the districts under investigation. The total irrigation requirement for the most relevant crops cultivated in each irrigation district was computed following Masia [11]. 
The distribution of the total irrigated crop area is obtained from national statistics, ISTAT [12].

\subsection{Runoff coefficient}

The runoff coefficient is computed as the ratio between gridded mean composite dataset of runoff field, obtained through the combination of observed river discharge with simulated water balance [13], and gridded mean of precipitation from Willmott et al. [14] database, both computed over the 1950 to 2000 period at spatial resolution of 30 minutes.

\subsection{Evaporation from the reservoir surface}

The simplified Penman-Monteith equation [15] is applied to estimate total water evaporated from reservoir surfaces. Climate data described in Section 2.3 and 2.4 are used to estimate evaporation values for the baseline and the future projections under RCP 4.5 and 8.5 scenarios.

\subsection{Irrigated agriculture resilience and vulnerability}

In this work, the recharge and the vulnerability indicators were developed and used to give a measure of reservoir resilience and vulnerability under climate change conditions.

The recharge indicator (eq. 1) was applied to estimate reservoir resilience in terms of the extent to which a reservoir can be recharged on average over a year once irrigation water and open water evaporation have been accounted for.

$$
\text { Recharge indicator }(\mathrm{RI})=\frac{W I-(W D+E)}{\operatorname{Cap} M C M} \quad \text { eq. } 1
$$

where $W I$ is the annual water entering in the reservoirs (Mm3), WD is the water used for irrigation for a combination of representative crops $\left(\mathrm{Mm}^{3}\right), E$ is the reservoir surface evaporation $\left(\mathrm{Mm}^{3}\right)$, and Cap $M C M$ is the dam capacity $\left(\mathrm{Mm}^{3}\right)$. Ratios less than one imply that recharge is not, on average, able to completely recharge the reservoir once irrigation and evaporation are accounted for.

A measure of reservoir vulnerability is provide by the vulnerability indicator (eq.2):

$$
\text { Vulnerability indicator }(\mathrm{VI})=\frac{R I(\text { future })-R I(\text { baseline })}{R I(\text { baseline })} \quad \text { eq. } 2
$$

The greater the difference between current and future states, the greater the change in vulnerability depending on the direction of change.

\subsubsection{Classes of resilience and vulnerability}

Both resilience and vulnerability indicators were defined into classes (Table 2 and Table 3) to assess the status and the trend of reservoirs in current and future period. 


\begin{tabular}{|c|c|c|c|c|c|}
\hline $\begin{array}{l}\text { Class of } \\
\text { resilience }\end{array}$ & Definition & Value & $\begin{array}{c}\text { Class of } \\
\text { vulnerability }\end{array}$ & Definition & Value \\
\hline A & Highly resilient & $\mathrm{Rl}>1$ & A & Highly vulnerable & $\mathrm{VI}<-1$ \\
\hline B & Resilient & $0.50 \leq \mathrm{RI} \leq 1$ & B & Vulnerable & $-1 \leq \mathrm{VI} \leq-0.5$ \\
\hline c & Moderately resilient & $0.20 \leq R I \leq 0.50$ & c & Moderately vulnerable & $-0.50 \leq \mathrm{Vl} \leq-0.20$ \\
\hline D & Slightly resilient & $0 \leq \mathrm{RI} \leq 0.20$ & D & Slightly vulnerable & $-0.20 \leq \mathrm{VI} \leq 0$ \\
\hline E & No resilient & $\mathrm{RI}<0$ & $\mathbf{E}$ & Not vulnerable & $\mathrm{vl}>0$ \\
\hline
\end{tabular}

Table 2: Classes, definitions, and values of reservoir resilience to climate change (left). Table 3: Classes, definitions, and values of reservoir vulnerability to climate change (right).

For a given reservoir capacity, the resilience of the irrigated agriculture under climate change conditions change as a function of the net annual volume entering into the reservoir. The higher recharge capacity is shown by reservoirs characterized by a smaller capacity. On an equal net water inflow, reservoir characterized by a smaller capacity are more resilient because of their higher annual recharge. Resilience reduction is due to decreasing values of annual water inflow and increasing values of water outflow. A lack of resilience is shown when the annual mean outflow is not compensated by an annual water amount entering into the reservoir higher or at least equal to water outflow. The vulnerability of the irrigation system tends to decrease when the values of change in water inflow are higher than changes in water outflow. The reservoir vulnerability to future climate changes is directly proportional to the index of vulnerability. Reservoirs with larger capacity relative to water demand are generally considered more resilient to adsorb water budget changes [16].

\subsection{Temporal Self-Sufficiency in Demand Capacity (TSSDC) and Allowable Water Losses for Irrigation (AWLI) indicators.}

In this work, we proposed a set of indicators that can be used to quickly assess operational criticalities of reservoirs to sustainably fulfil irrigation water demand for specific irrigation district.

The Temporal Self-Sufficiency in Demand Capacity (TSSDC) indicator is expressed in years and it measures for how long a given reservoir could supply the requisite irrigation and evaporation requirements under the assumption of a complete cut off in reservoir inflow. While perhaps representing an unrealistic scenario, the indicator gives a representation of for how long a specific reservoir is able to meet demand under extreme drought conditions. For lower crop water demand and reservoirs characterized by higher recharge volume, this time is expected to be longer than the opposite situation (eq. 3, Table 4).

In terms of vulnerability, this is computed as a relative change to baseline conditions (eq. 4, Table 4). The larger the change, the greater the change in vulnerability, with the direction of change reflecting the change in vulnerability where positive values represents a decrease in the system vulnerability and vice-versa.

The theoretical maximum allowable water losses in an irrigation distribution system that would result in all the inflow being used (i.e. leaving a net zero recharge to the reservoir) is estimated through the Allowable Water Losses for Irrigation (AWLI) indicator (eq. 5, Table 4).

The related vulnerability indicator (eq. 6, Table 4) highlights the need for improvement in system efficiency that would be required to offset future climate and irrigation changes in order to maintain baseline system efficiencies. 


\begin{tabular}{|l|c|}
\hline \multicolumn{1}{|c|}{ Indicators } & \multicolumn{1}{c|}{ Vulnerability indicators } \\
\hline $\begin{array}{l}\text { TSSDC }=\text { if }(\mathrm{WI}> \\
\left.\text { Cap MCM; } \frac{\text { Cap MCM }}{(\mathrm{WD}+\mathrm{E})} ; \frac{\mathrm{WI}-(\mathrm{WD}+\mathrm{E})}{(\mathrm{WD}+\mathrm{E})}\right)(\mathrm{yr}) \text { eq. } 3\end{array}$ & TSSDC $_{\boldsymbol{V} \boldsymbol{I}}=\frac{\text { TSSDC (future) }- \text { TSSDC (baseline) }}{\text { TSSDC (baseline) }}$ eq. 4 \\
\hline $\begin{array}{l}\mathbf{A W L I}=\text { if }(\mathrm{WI}>\mathrm{Cap} \mathrm{MCM} ; 100 *[1- \\
\left.\left.\left(\frac{\mathrm{WD}}{\mathrm{Cap} \mathrm{MCM}-\mathrm{E}}\right)\right] ; 100 *\left[1-\left(\frac{\mathrm{WD}}{\mathrm{WI}-\mathrm{E}}\right)\right]\right) \text { eq.5 }\end{array}$ & AWLI $_{\boldsymbol{V} \boldsymbol{I}}=\frac{\text { AWLI (future })- \text { AWLI (baseline) }}{\text { AWLI (baseline })}$ eq. 6 \\
\hline
\end{tabular}

Table 4: Temporal Self-Sufficiency in Demand Capacity (TSSDC) and Allowable Water Losses for Irrigation (AWLI) indicators and their related vulnerability indicators.

\section{Results and discussions}

Precipitation values are expected to decrease in each case study with an unavoidable water reservoir inflow reduction particularly evident under RCP 4.5 except for Cuga-Alto Temo system where the strongest impact is expected under the worst scenario. The mean basin annual precipitation values ranged from 492 to $378 \mathrm{~mm} \mathrm{yr}^{-1}$ for the baseline, and the highest differences between future and past values are computed in Stretta di Calamaiu, and the lowest in the system (Table 5).

Similar crop water demand values for the baseline (about $6 \mathrm{Mm}^{3}$ ) and similar difference between future and baseline total water used for irrigation $\left(0.43-0.57 \mathrm{Mm}^{3}\right)$ are estimated in the Gallura and Basso Sulcis irrigation districts, both characterized by a similar irrigated area. The highest crop water demand is expected in the Nurra district, in correspondence with the largest irrigated area (4704 ha). The annual amount of evaporation from the open surface range from 7 to $8 \mathrm{Mm}^{3}$ in Monte Pranu and Cuga-Alto Temo systems, and is lower in Stretta di Calamaiu about $\left(6 \mathrm{Mm}^{3}\right)$.

Stretta di Calamaiu and Monte Pranu reservoirs are characterized by a certain level of resilience (class B, Table 2) in the baseline and under RCP 4.5 that is expected to decrease (class C, Table 2) under the worst scenario. The lowest resilience (class D, Table 2) in both baseline and future climate conditions and the highest vulnerability (class C, Table 3 ) is estimated in Nurra district served by the Cuga-Alto Temo system that is able to annually recharge only the $8 \%$ of the reservoir during the baseline, and values tend to decrease under RCPs (about $-4 \%$ ). Under prolonged drought conditions, Cuga-Alto Temo system is the most vulnerable due to its low recharge capacity and the increasing values of water required to irrigate the fields in the district. The system is able to satisfy irrigation demand for less than one year. The most resilient (almost 5 years in the baseline and about 4.3 under future climate) is Stretta di Calamaiu, and it is explained by the small irrigated crop distribution in Gallura district. Vulnerability tends to increase as a function of water deficit, where resilience is mostly related to storage capacity, but also to water use efficiency in the irrigation system and system management capacity. In this regard, the Cuga-Alto Temo system shows the highest vulnerability with relative changes under future climate of allowable water losses for irrigation that range from $-45 \%$ to $30 \%$. In this work AWLI of most reservoirs was higher than $80 \%$ except for the system where the low AWLI is related to the fact that all water inflow can be hardly used for irrigation demand (e.g. rainfall concentrated in limited period of the year) especially if the reservoir capacity is quite limited.

According to the approach adopted, in general most reservoirs studied are considered resilient to climate change despite the decreasing projected future mean precipitation, and its portioning into runoff, and future crop water demand increases. This is mostly due to their storage capacity which is sufficient to buffer the irrigation water demand during dry seasons. This is an important finding for local water and reservoir managers: the reservoir size itself generally is sufficient to allow for resilience to future input and demand changes. However, imbalances between water demand and supply have occurred in some of these systems, suggesting that water management and/or infrastructures do not allow for the most efficient resource use. In this sense, the vulnerability indicators should be seen as a degree of intervention on infrastructures and water use policies to be added to the present needs. 


\begin{tabular}{|c|c|c|c|c|c|c|}
\hline Ir-Ds & \multicolumn{2}{|c|}{ Gallura } & \multicolumn{2}{|c|}{ Nurra } & \multicolumn{2}{|c|}{ Basso Sulcis } \\
\hline \multirow[t]{2}{*}{ Reservoir } & \multicolumn{2}{|c|}{ Stretta di Calamaiu } & \multicolumn{2}{|c|}{ Cuga-Alto Temo } & \multicolumn{2}{|c|}{ Monte Pranu } \\
\hline & $4.5-b$ & 8.5-b & $4.5-b$ & $8.5-b$ & 4.5-b & 8.5-b \\
\hline Maximum Capacity $\left(\mathrm{Mm}^{3}\right)$ & \multicolumn{2}{|c|}{105.2} & \multicolumn{2}{|c|}{127.4} & \multicolumn{2}{|c|}{62} \\
\hline WI $\left(\mathrm{Mm}^{3}\right)$ & -10 & -13 & -3 & -1 & -4 & -8 \\
\hline $\mathrm{WD}\left(\mathrm{Mm}^{3}\right)$ & 0.53 & 0.51 & 1.77 & 1.73 & 0.56 & 0.43 \\
\hline $\mathrm{E}\left(\mathrm{Mm}^{3}\right)$ & 0.51 & 0.69 & 0.68 & 0.84 & 0.56 & 0.75 \\
\hline CWS $\left(\mathrm{Mm}^{3}\right)$ & -11.04 & -14.20 & -7.08 & -5.69 & -5.02 & -9.25 \\
\hline VI (fraction) & -0.17 & -0.23 & -0.53 & -0.35 & -0.13 & -0.24 \\
\hline TSSDC-VI (fraction) & -0.24 & -0.30 & -0.56 & -0.40 & -0.20 & -0.30 \\
\hline$A W L I-V I(\%)$ & -2.57 & -3.18 & -45.92 & -30.14 & -3.34 & -5.06 \\
\hline
\end{tabular}

Table 5. Differences of annual water inflow (WI), crop water demand (WD), evaporation loss (E), cumulated water shortage (CWS), vulnerability index (VI), Temporal Self-sufficiency in Demand Capacity index $\left(\mathrm{TSSDC}_{V I}\right)$, and Allowable Water Losses for Irrigation index $\left(\mathrm{AWLI}_{V I}\right)$. Changes are reported between baseline (b, 1976-2005) and future (2036-2065) climate under RCP4.5 and 8.5.

\section{References}

[1] IPCC, 2013. Summary for Policymakers. In: Climate Change 2013: The Physical Science Basis. Contribution of Working Group I to the Fifth Assessment Report of the Intergovernmental Panel on Climate Change. Stocker, T.F. et al. Cambridge University Press, Cambridge, United Kingdom and New York, USA.

[2] Bates, B.C., Kundzewicz, Z.W., Wu, S., Palutikof, J.P., 2008. Climate change and water. Technical Paper of the Intergovernmental Panel on Climate Change, IPCC Secretariat, Geneva, $210 \mathrm{pp}$.

[3] Tanasijevic, L., Todorovic, M., Pereira, L.S., Pizzigalli, C., Lionello, P., 2014. Impacts of climate change on olive crop evapotranspiration and irrigation requirements in the Mediterranean region. Agricultural Water Management 144, 54-68.

[4] Yano, T., Aydin, M., Haraguchi, T. 2007. Impact of climate change on irrigation demand and crop growth in a Mediterranean environment of Turkey. Sensors 7, 2297-2315.

[5] Lehner, B., Reidy Liermann, C., Revenga, C., Vörösmarty, C., Fekete, B., Crouzet, P., Döll, P., Endejan, M., Frenken, K., Magome, J., Nilsson, C., Robertson, J., Rödel, R., Sindorf, N., Wisser, D., 2011. High resolution mapping of the world's reservoirs and dams for sustainable river flow management. Frontiers in Ecology and the Environment 9 (9), 494-502, http://dx.doi.org/10.1890/100125.

[6] Scoccimarro, E., Gualdi, S., Bellucci, A., Sanna, A., Fogli, P.G., Manzini, E., Vichi, M., Oddo, P., Navarra, A. Effects of tropical cyclones on ocean heat transport in a high resolution coupled general circulation model. J. Clim. 2011, 24, 4368-4384, doi:10.1175/2011JCLI4104.1.

[7] Gualdi, S., Somot, S., Li, L., Artale, V., Adani, M., et al. The CIRCE simulations: Regional Climate Change Projections with Realistic Representation of the Mediterranean Sea. Bull. Amer. Meteor. Soc., 2013, 94 (1), pp.65-81. 
[8] Snyder, R.L.; Geng, S., Orang, M.N., Matyac, J.S., Sarreshteh, S. A simulation model for ET of applied water. Acta Hortic. 2004, 664, 623-629.

[9] Snyder, R.L., Geng, S., Orang, M., Sarreshteh, S. Calculation and Simulation of Evapotranspiration of Applied Water. Integr. Agr. 2012, 11 (3), $\quad$ 489-501, https://doi.org/10.1016/S2095-3119(12)60035-5.

[10] Mancosu, N., Spano, D., Orang, M., Sarreshteh, S., Snyder, R.L. SIMETAW\# - a Model for Agricultural Water Demand Planning. Water Resour. Manag. 2015, doi:10.1007/s11269-015-1176-7.

[11] Masia, S. A modeling tool to assess local and regional impact of climate change on crop water requirement in Euro-Mediterranean Countries, and assessment of Mediterranean irrigated agriculture vulnerability, PhD thesis, University of Sassari, 2017.

[12] ISTAT, 2010. Censimento Agricoltura 2010.

http://daticensimentoagricoltura.istat.it/Index.aspx?lang=it\# (2017).

[13] Fekete, B.M., Vörösmarty, C.J., Grabs, W. 2000. Global, Composite Runoff Fields Based on Observed River Discharge and Simulated Water Balances. Report No. 22. Global Runoff Data Centre (GRDC), Federal Institute of Hydrology (BfG) Koblenz, Germany.

[14] Willmott, C.J., Matsuura, K. Terrestrial Air Temperature and Precipitation: Monthly and Annual Time $\quad$ Series $\quad$ (1950 http://climate.geog.udel.edu/ climate/html_pages/README.ghon_ts2.html 2001. UDel_AirT_Precip data provided by the NOAA/OAR/ESRL PSD, Boulder, Colorado, USA, from their Web site at http://www.esrl.noaa.gov/psd/.

[15] Allen, R.G., Pereira, L. S., Raes, D., Smith, M., Crop evapotranspiration: Guidelines for computing crop requirements. Irrigation and Drainage Paper No. 56, FAO 1998, (56), 300, https://doi.org/10.1016/j.eja.2010.12.001.

[16] Mereu, S., Sušnik, J., Trabucco, A., Daccache, A., Vamvakeridou-Lyroudia, L., Renoldi, S., Virdis, A., Savić, D., Assimacopoulos, D. Operational resilience of reservoirs to climate change, agricultural demand, and tourism: A case study from Sardinia. Sci. Tot. Environ. 2016, 543, 1028 1038, https://doi.org/10.1016/j.scitotenv.2015.04.066. 